\title{
Anthrovision
}

Vaneasa Online Journal

Vol. 7.2 | 2019

Epistemic Disobedience

\section{A Collaborative Filming Method with Characters and Crew}

Reflection on the Making of the Short Documentary Film Ghetto PSA

\section{Rossella Schillaci}

\section{(2) OpenEdition \\ Journals}

Electronic version

URL: http://journals.openedition.org/anthrovision/5908

DOI: 10.4000/anthrovision. 5908

ISSN: 2198-6754

\section{Publisher}

VANEASA - Visual Anthropology Network of European Association of Social Anthropologists

\section{Electronic reference}

Rossella Schillaci, "A Collaborative Filming Method with Characters and Crew", Anthrovision [Online],

Vol. 7.2 | 2019, Online since 10 November 2020, connection on 26 January 2021. URL: http://

journals.openedition.org/anthrovision/5908 ; DOl: https://doi.org/10.4000/anthrovision.5908

This text was automatically generated on 26 January 2021.

(c) Anthrovision 


\title{
A Collaborative Filming Method with Characters and Crew
}

\author{
Reflection on the Making of the Short Documentary Film Ghetto PSA
}

Rossella Schillaci

\section{Introduction}

1 This article aims to reflect on the collaborative methodology applied in the production of a short documentary film made in 2016, entitled Ghetto PSA.

2 I will describe the main challenges faced during fieldwork and shooting to draw attention to the concepts of collaboration, authorship and transculturality. In particular, the collaborative practice will be analysed focusing on the constraints and limitation encountered in the stages of the production, focusing particularly on the development, and related to all the different figures connected to it: the producer, the characters, the crew.

3 I will discuss how a process of negotiation has been inevitable, embracing a participative approach that brought the project into the territory of ethnofiction. This process contributed to the achievement of a 'transcultural' dialogue fundamental for anthropological film-work, as already conceptualized by David MacDougall (1998) and Jean Rouch (2003). 
Figure 1. The main character of the film, Jacob

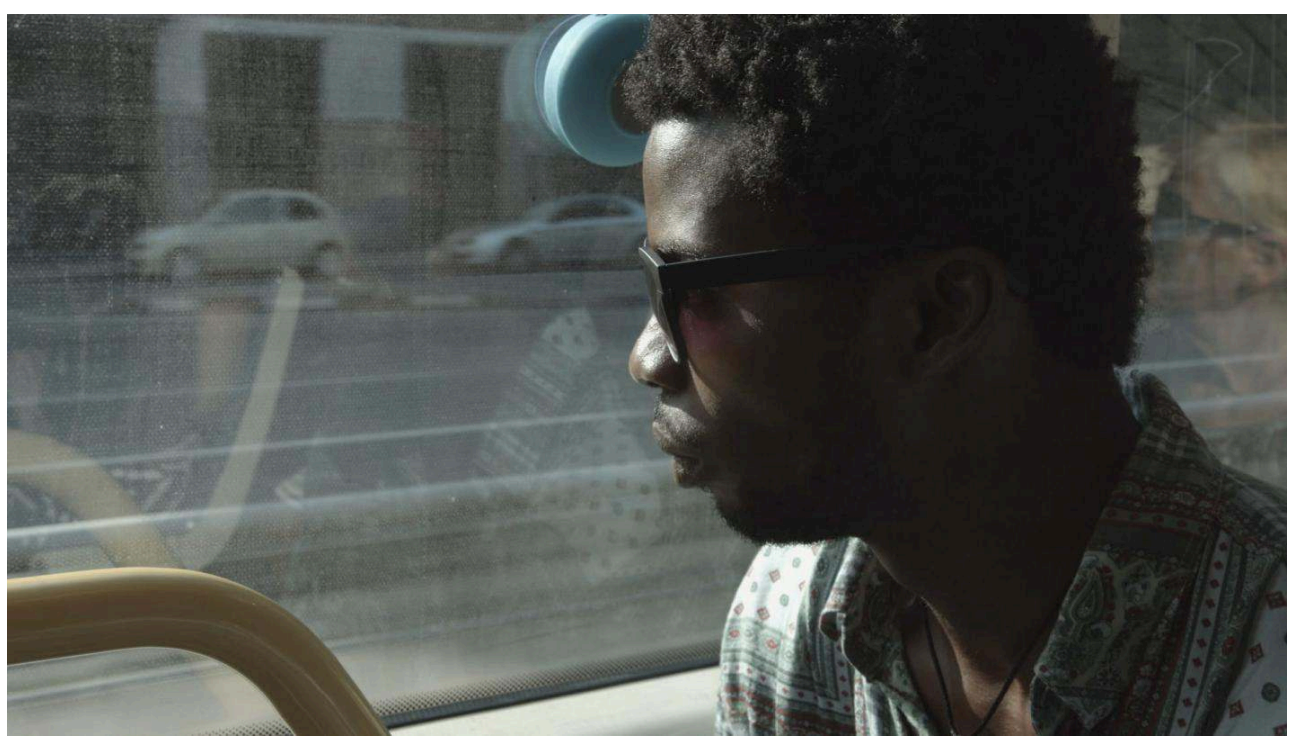

Screenshot from film Ghetto PSA by Rossella Schillaci, 2016

\section{The Production of the Film GHETTO PSA}

Ghetto $P S A^{1}$ is a short documentary film of 15 minutes produced in 2016 by the company Una Film in collaboration with Azul Film, financed by the Italian Minister for Culture (MIBAC Ministero per i beni e le attività culturali). The film premiered at the Venice Film Festival in 2016 and has since been screened in international film festivals, like the Royal Anthropological Film Festival, the African Film Festival in Milan, the NAFA film festival, and it was the only Italian film selected to be premiered at the American Cinematheque during the event 'Starring EU' held in Los Angeles in 2018.

5 The film portrays the daily life of a young Guinean man living in Italy, Jacob (Figure 1). This is the synopsis of the film as presented in the press kit and in the festivals' catalogue: "Jacob arrived in Italy alone from French Guinea when he was 11 years old. Today he is 27, and hip-hop music is his whole world: it is his way to express dreams, hopes and frustrations, and to not feel part of the 'ghetto' any longer. He lives on the outskirts of Turin where, by day, together with other young migrants who are part of his band 'Ghetto PSA', he writes songs and makes music. At night, he works as an educator in a centre for asylum seekers. This 'double life' leads him to reflect on his own identity, as a young Italian who speaks three languages, but who does not forget who he is and where he comes from."

\section{The Idea and the Development of the Film}

6 For a filmmaker, the reasons to make a film are often very personal and vary from project to project. In the case of Ghetto PSA the idea came up to meet a special call for funding announced by the Italian Minister for Culture (MIBAC - Ministero per i beni e le attività culturali). The call aimed to finance the production of short films, fiction or documentaries, of a maximum duration of 15 minutes, concerning stories relating to the culture and the local reality of foreign communities residing in Italy, with 
particular reference to the new generations. The call was very competitive: it was addressed to the national territory and could select only 15 projects in total. The general purpose of this initiative was to screen the selected films in festivals, conferences and special events for increasing the public awareness about immigrants' life conditions in Italy. The call was published on December 2015, the deadline for the proposals presentation was the end of January 2016, the results were communicated in April 2016 and the selected films needed to be delivered by the end of July 2016, or else the funding would be withdrawn.

7 I'm writing all these details to explain how important it is to reflect on choices about filmic approach precisely from the beginning, starting from the commission. Usually, behind a documentary film production there could be different institutions who give their support, such as research foundations, universities, a public institution or a television broadcaster. In all these cases there are specific requests, editorial guidelines, ethical principles and practical conditions to respect, although the circumstances differ and they can be more explicit or rigid, or less clear and flexible. The author's freedom and responsibility start from the recognition of all the terms and conditions, financial or practical. The author can accept or modify them if possible, and can understand if his or her project can be developed under that framework.

In my case, the only commissioner was the Ministry itself, which had already requested in the call for proposals a very detailed artistic project and severe bureaucratic procedures to be respected. I had to understand which project I could prepare with these strict conditions: maximum duration of 15 minutes and a worryingly short time not only for preliminary research, but also for the shooting and the editing phases. As underlined by many scholars (for example Grimshaw and Ravetz 2009) a fundamental pre-condition in anthropological films is the time that is needed to create, above all, a relationship of trust between the filmmaker and his or her subject.

\section{The Previous Research}

9 Initially, I thought about a previous anthropological fieldwork conducted in 2011 and 2012 in a multi-disciplinary team, which dealt with the same topics of the call. The project was called Concordia Discors and it was a comparative and participatory research on integration among groups of different origins, in European neighbourhoods ${ }^{2}$. One of these neighbourhoods in Italy was Barriera di Milano, a semi-central working-class quarter, located in the north of Turin, my city. It had once been one of the city's main industrial areas, but now it is the area with the most abandoned factories and the highest level of unemployment. Despite the economic decline of the quarter, minorities of migrant origin are living there, mainly attracted by low housing prices (Conforti and Mela 2006, Ciampolini 2007). As a consequence, Barriera, among the city quarters, is the one which shows the worst social profile: it is more densely inhabited, multi-ethnic, young and socially weaker compared to the city average. However, the presence of foreign residents is often regarded as the cause of urban blight rather than the other way round:

"Italian cities are deeply transformed by immigration. Not only in their demographic composition, but also in the way of living the public space, in relationships and forms of aggregation among citizens, in the challenges for local governments. In this metamorphosis, the neighbourhood is the key dimension, the level to which abstract concepts, such as integration, are translated into concrete 
experiences, in feelings of novelty or unease, in new forms of cooperation or

conflict." (Pastore and Ponzo, 2012)

10 A fundamental assumption of this project is that integration is a dynamic achievement and it is not a rigid state nor the conceptual opposite of conflict.

In this framework, I conducted fieldwork which led to the production of a short film, Frontiera Interna (2012) ${ }^{3}$. This short documentary followed two group of inhabitants: a group of old Italian men who had lived more than fifty years in the quarter, and a group of young African immigrants, who arrived there more or less ten years ago. The 20 minute film tried to thematize and analyse the inter-group tensions inevitably associated with integration processes. Since then, I have been in contact with one of the main characters, Jacob, with the idea to produce in the future a documentary only about him, in order to give more time and space to his vision about the quarter, which in his songs he called 'the ghetto'. 'Ghetto PSA' (PSA: Puro Sangue Africano, Pure African Blood) is also the name of his hip hop group which includes other African rappers, and despite the name, young Italians as well. For them, Barriera di Milano is a more complex and undoubtedly problematic reality, but at the same time a lively quarter full of opportunities. The lyrics of their songs tell of 'cops', racism and discrimination, but also of integration and passion for their city. One of the features that stands out is the strong sense of belonging common both to Italians and foreigners. This 'feeling part' of a community, however complex and conflictual, generates a particular ferment and makes this district a dynamic territory full of social experiments and initiatives. Here several cultural associations and NGOs are based, which carry out cultural and integration projects, like the 'Public Showers of via Agliè's. This cultural association actually has public showers which anyone can use for less than 2 euros. But it has 'old' shower boxes which are not used anymore, that are now given to residents to carry out their cultural projects. Here Jacob and the other members of his group, often go to record their texts and music.

They also go to public gardens for improvised freestyle sessions with other youngsters from the neighbourhood, both Italians and foreigners. For them, music is a way to express their anger, but also their hope. Music is, above all, their personal key to access in a neighbourhood where many, especially the elderly, find it difficult to accept them for what they are, seeing them only as 'blacks' or, worse, as 'niggers'. One cannot fail to be impressed by their strength and purposefulness, and the originality with which they use rap and their passion for music to make themselves known, to create relationships, and to try to live peacefully in what is now their city.

\section{Methodology: The Collaboration with the Main Character in the Building of a New Filmic Project}

13 Following the theories of Nicolas Mirzoeff (2011, 2015), I decided to answer the call for the short film production to give a 'counter-account' and to question the "ways of seeing" of my characters. The aim for me was to create a film and not only scientific knowledge. But with the purpose of creating a project that would represent Jacob's and his friends' point of view, providing a counter-narrative of young immigrants living in Italy for more than 10 years. 

in a long interview with him that w use in the editing as a narrative voice over for the film. As I did in previous films, such as Other Europe $(2011)^{5}$ and Shukri, a New Life $(2011)^{6}$, I wanted to tell the story of these young immigrants through their own voices. In this project, I was interested in letting the character's own words emerge; his ideas about the present life in his 'ghetto', but also his past and all the difficulties he had gone through since his arrival in Italy. Jacob had a very sad childhood. After the death of both his parents, he came alone to Italy at the age of 11. After several problems, as he said, the educators in a community helped him and 'saved his life'. For me it was important to tell how his identity and sense of belonging changed during this period, after several experiences lived in different countries, such as Guinea, France and then many cities in Italy. As Stuart Hall points out (cited in the call for this special issue), "Cultural identity [...] is a matter of 'becoming' as well as of 'being'. It belongs to the future as much to the past. It is not something which already exists, transcending place, time, history, and culture. Cultural identities come from somewhere, have histories" (1990: 225).

But my idea had to change. In fact, Jacob was perplexed by this choice of style and of content. He knew that the film was going to be screened in festivals and definitely also in his neighbourhood. He didn't want to reveal too much of his past, he was afraid of bad repercussions. Moreover, he told me he was not very keen on being interviewed, because his way of expressing himself was with music and with rap songs. In a 'decolonial' path, this was the first big moment of reflection that necessarily led to a big negotiation. The approach I chose to tell his story didn't meet with Jacob's approval. During this process of exchange, I also realized that it was impossible for me to use an observational style, as I did in other documentaries, for example Practice and Mastery $(2005)^{7}$ or Imprisoned Lullaby (2016) ${ }^{8}-9$. With Jacob, we discovered a complex core of situations, places and people connected to his life, which would take a long time to follow with the camera. As Anna Grimshaw nicely puts it:

"to work observationally requires a certain courage and determination. It involves following one's hunches, and embarking on a journey of exploration in which the endpoint, the film, is not known in advance. It is a risky and often frustrating enterprise [...]. Sometimes pursuing an observational approach fails to lead anywhere interesting" (2007: 5).

When I received the communication that the project had been selected, I had less than four months to deliver the finished film. This limited time, and the responsibility taken with the producer and the Ministry, convinced me that for this project I simply could not risk embarking on an open-ended observational film. 
20 I was mainly interested in exploring, as Worth and Adair wrote, "how a group of people structure their view of the world - their reality - through film" (1972: 7). So I decided to change the stylistic approach completely and abandoned the idea of doing an observational film. I proposed to Jacob to 'do a film together' based on his everyday life and his perceptions of the place where he was living and working. As underlined by Remillet and Wanono, in the last few years there have been numerous projects developed within a collaborative framework which "reintroduce well-known concepts such as that of 'shared knowledge', and make forms of hybrid production possible" (2014:1). This 'hybrid production' offers a glimpse of a multiplicity of practices and narratives, that questions the notion of fieldwork, the notions of authorship and narrativity.

21 Jean Rouch's approach of shared anthropology and 'ethnofiction' influenced the development of this new project. For me, it would be a good occasion to experiment with a new form of storytelling, so I proposed to Jacob a 'hybrid' film that was half written and half improvised. Welcoming his engagement and talent, I asked him to be the author of the music and to write a song which would talk about him, about his past and his life in the neighbourhood. Unlike an interview, in writing the song he could be free and carefully select what to say and what to reveal or not.

However, concerning the general production of the film as a whole, it was clear for me from the beginning that the authorship could not be equally shared. I was aware that there was an asymmetrical relationship between the character and the filmmaker, and differences in filmmaking knowledge. In my opinion, in general, it is the filmmaker who that should take ultimate responsibility for the authorship of the film, since he or she is usually the one in charge, as it has already conceptualized (Henley 2009, 2010). Depending on different production commissioners, usually there are demanding duties to fulfil, such as meeting hard deadlines, not exceeding the budget, and respecting social and security laws on shooting with all the crew and the personnel involved. In particular, for this project, as author and filmmaker, I had to sign a contract with the producer and the Ministry, committing to finish within 3 months a film of only 15 minutes duration, that would develop a narrative structure that was enjoyable for the viewer, and that would have high enough cinematic quality to be screened in film festivals. I explained these circumstances to Jacob very clearly. For him it was acceptable, as long as he could share and agree upon the main contents of the film, which it would remain respectful of his point of view and avoid putting him in uncomfortable situations in 'real' life.

23 Therefore, we collaborated on the writing of the film, building a new structure based on a 'typical' day in his life, from the morning until the following morning. We discussed what could be the relevant moments and what Jacob would want to show, which areas and places in the neighbourhood were significant for him and why. In addition, part of the story would be the process of 'making the song'. The film would show how, where and when he would usually 'throw the rhymes down' and sing them on a musical base, as he usually does, either alone or with the other members of his group. The process of writing the song, in our shared scenario, would be intercut with his daily activities.

24 In this case the terms 'writing' and 'script' need to be revisited. My landmark and point of departure was a specific type of scenario mainly used in Italian Commedia dell'arte, a form of popular theatre that flourished first in Italy and then throughout Europe from 
the 16th through the 18th century. A commedia, a collection of improvised performances, is based on this unique type of scenario, called the canovaccio (Chaffee and Crick 2015). The canovaccio serves as an outline which provides the track on which the actors' theatrical improvisation develops. It is a list of the main actions and content, and functions as a sort of reminder for the actors, but gives no detail or dialogue. In Commedia dell'arte the main development of every scene was, in fact, not scripted but improvised at the moment, on stage (Testaverde 2007).

Writing about her own experience, Jenssen uses the word 'challenge': "it is challenging to create an acceptable representation which violates neither 'truth' nor the involved people, while at the same time fulfilling aesthetic needs" (2009: 17). In our case, the challenge was to find a sort of 'communicative meaning' for the subject (Jacob), and the filmmaker (me) but also for the viewers. For this project, the scenario was a list of selected main scenes of the film. This was the necessary tool to find a 'meaningful narrative structure' and an aesthetic approach to convey these meanings. For the character, it was through this instrument that his perspective could be 'truthfully' respected. It was essential that this process of writing was long enough to incorporate all the preliminary research, the fieldwork and the agreement with the characters about what to shoot. I understood that it was of fundamental importance to dedicate as much time as possible to this phase, since the shooting could last only few days, due to budget constraints.

As said before, the notion of fieldwork took on special features at this point. Fieldwork was now aimed at finding of the main scenes that would build the narrative; it was strictly interconnected with the writing and vice versa. I did part of the research alone, re-discovering the neighbourhood and comparing it with the discovery of the research conducted in 2012. In a second phase, Jacob accompanied me, guiding me in the places he used to live. He introduced me to his friends and to the other characters. We shared 'our' project with them, seeking their collaboration and authorization to be part of it. It was a long process of discussion and negotiation. In fact, there were also situations that we decided to not include, in order to respect the will of people who didn't want to be filmed, or to protect characters from unpleasant consequences.

On the other hand, Jacob's new job became more important in our story. For a few months, he had been employed as social worker (a kind of educator, but with fewer responsibilities) in a centre for asylum seekers. For him, this centre was the 'real ghetto', rather than the quarter (Barriera di Milano) where he had been living. Located quite far from the city centre, in a structure owned by Catholic Missionaries, this organization offered very few opportunities for the young African immigrants to integrate themselves in the host society. They spent almost all their time indoors, especially in late spring and summer, the period of my research. On the contrary, Jacob was showing me how his neighbourhood was difficult, but at the same time offered multiple occasions to interact and find ways to integrate foreigners. This 'double life', half spent in Barriera, and half in the Missionary Centre, led him to reflect on his own identity and past experiences. I understood that for my character this job was crucial in this phase of his life, still in a period of insecurity about the future and reflection about his past. The inclusion of this part was source of discussion and negotiation, especially with the third parts involved. In fact, it was not easy to film in the centre for asylum seekers, as it was under the responsibility of the State Prefecture. Many refugees were under 18 years old and there were many tensions between them. Together with the 
production company, I took all the necessary precautions and conducted special fieldwork for a long period of time in the centre, sometime alone, sometimes with the character, sometimes with the producer and the crew. We agreed with the managers of the centre on a series of rules of behaviour, and on a way to allow Jacob to be filmed while doing his job. We filmed only the young refugees who were very keen to know Jacob better and to be part of this filmic experience, which in their eyes was a great opportunity to express themselves and experience 'cinema production'.

\section{Collaboration During the Shooting} with high cinematic quality. Together with the producer, we decided to invest all of the small budget at our disposal in hiring a professional camera operator and crew, although for only a few days, since the budget was very limited, and we had already contributed some of our own personal funds to cover the other costs. But this was a way for us to take the challenge and experiment with a new form of production. The crew was composed of a cinematographer, a sound technician and an assistant producer, who was also in charge of storing the footage. I will not give too many details about the work with a professional crew, although it raises many interesting issues, because it goes beyond the scope of this article and needs to be described further elsewhere. However, this choice represents another important step in the collaborative process. I had the opportunity to reflect more about it, and I discovered how important it is to fully share the project and the approach with the technical staff involved. The collaboration with them had already started during the fieldwork. I explained them the rules of the game I was 'playing' with the character and then I listened to all their suggestions, opening up even more the negotiations already in play, which now involved not only the filmmaker and the character, but also the crew.

is important for me to say that the presence of all the technical apparatus professional camera and microphones, lights, tripods - and cinema professionals, instead of intimidating the character, enhanced his enthusiasm. The idea of being the protagonist not a 'simple' documentary (in his eyes), but in a 'real film' which might be exhibited in cinema festivals, intensified his participation. Moreover, the character and his friends, who were used to produce short video clips for their songs, were extremely curious and keen to learn more about image and sound recordings techniques. As a result, they built a strong relationship with the technicians, helping in many ways in the setting up of the equipment (sometimes they would 'do the ciak' (the clapper board to synchronize the audio to the images, as in Figure 2). The technicians, for their part, were quite open to this new form of collaboration and fully accepted the principles and the rules behind it. 
Figure 2. The main characters take the ciak

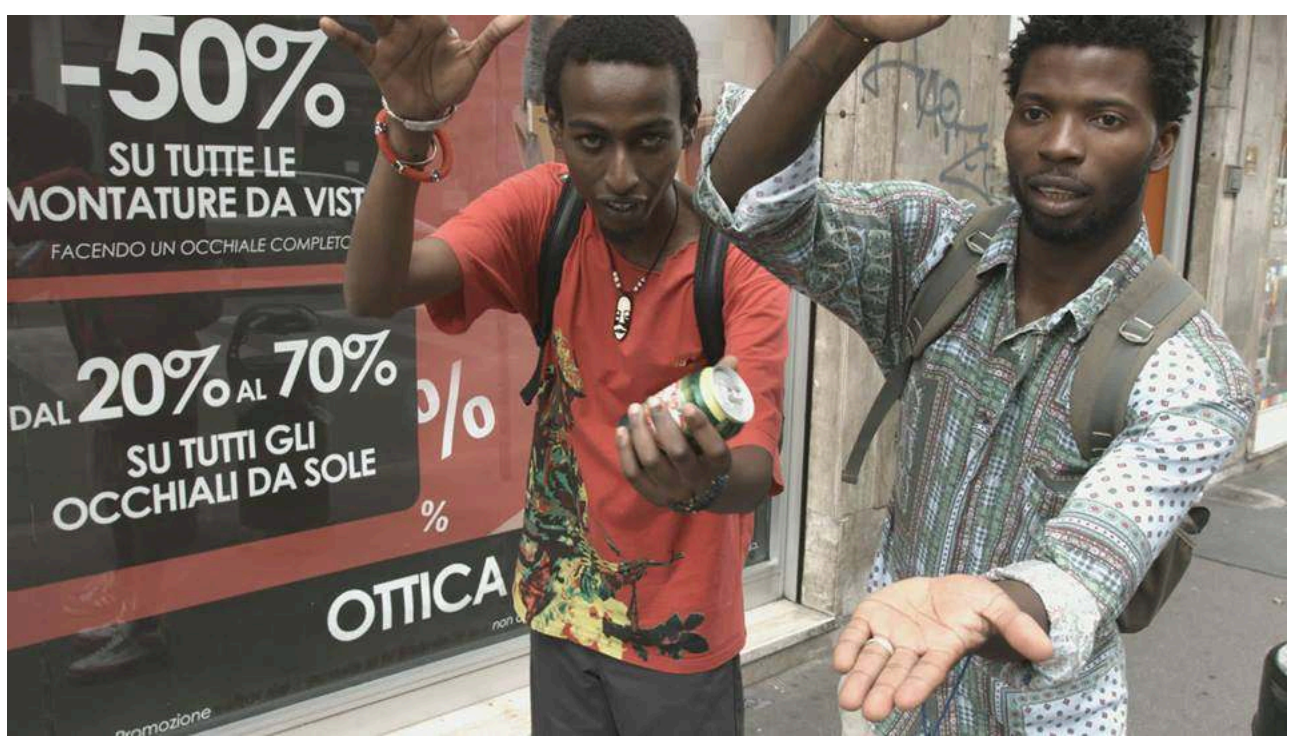

Screenshot from film by Rossella Schillaci, 2016 walking around the streets of the neighbourhood, the characters could do whatever and go wherever they wanted, and we would follow them with the camera held with the shoulder strap. The camera acted as a 'Rouchian' catalyst. Unexpected encounters took place between our protagonists and the people they met in the street, often in a joyful mood, which displayed many revealing moments about the neighbourhood's life and problems. When we shot at the asylum seekers' centre, we filmed a deep dialogue between the main character and Osman, a young refugee living in the centre. At the end of their conversation, Jacob leaves, and Osman is left alone on the bench. I asked to the cameraman not to stop and to keep on filming. I could feel that the dialogue had touched Osman's thought. Osman could feel as well that we were waiting there, ready to listen and record him. It was a calm and quit night, and the church bells started to play in the background. Unexpected, Osman started to sing, alone, 'Redemption song', with an emotional voice. It was a magic moment, at least for what we felt at that time. It was 'his' moment to communicate his own feeling and he decided to express himself through that song.

The pleasure of the experience of making a film, and the experience we lived together as a team, amplified the creative possibilities, living for the unpredictable, as in any 
observational film. We were open, attentive and ready to record what the characters would disclose in front of the camera. This 'perceptive' approach during the shooting creates a space where 'epiphanies' can happen: sudden manifestations of essential meanings, intuitive grasps of reality through simple and striking moments and discoveries.

Figure 3. The main character of the film in the recording studio, Jacob

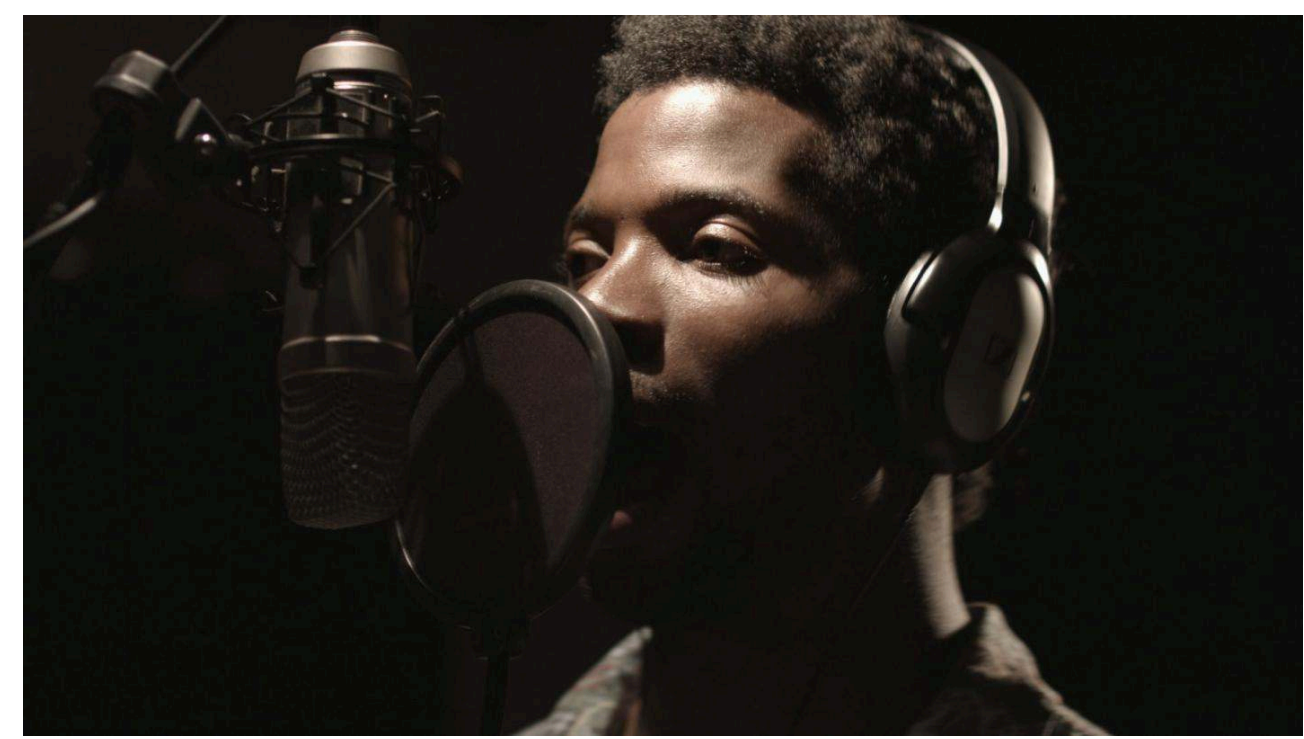

Screenshot from film by Rossella Schillaci, 2016

\section{Final Reflections}

When Jacob saw the last cut of the editing, he was impressed. He said that it was not a 'simple documentary' for him, but 'a real film', as he expected. He was very satisfied with the result and felt he had been completely portrayed. One month later, when we were told that the film had been selected to be premiered at Venice Film Festival, we were all very happy, but Jacob most of all. He used his blog, his Facebook and his YouTube channel to post everyday clips about his festival experience. When he came back to his city, he was interviewed by local newspapers and became 'famous' for a short period of time. We screened the film several times, followed by interesting debates about the quarter and the immigrant communities. The characters organized rap concerts and presentations in schools and cultural centres. Jacob, through the film and his songs, became a 'spokesman' for the young African people who were living in the area and the screening of the film invited a reflection upon their living conditions. Since then, Jacob has participated in several other cultural and transcultural projects, which has stimulated an awareness of their conditions through images and music.

Reflecting on the overall experience, as a filmmaker I could say that this project has been for me an important source of experimentation and search for new methods in the vast realm of anthropological storytelling. Dealing with film production constraints can be challenging, but at the same time can lead to new forms of cinematic models which can raise awareness about the topics not only in anthropological contexts but also for a broader audience. The collaborative approach applied with the characters 
and the whole crew went through a long process of discussion and negotiation. The practices used during the preparation, and mainly the writing of an agreed scenario, the canovaccio, brought about a transcultural action which left the characters open to reveal themselves. At the same time these practices helped the filmmaker and all the crew to do their job in the best possible way, considering all the constraints. Compromises are unavoidable; sometimes they are serious limitations in the process, but sometimes they can donate unexpected epiphanies concerning both the meanings and the method employed to reach them. I think that the method used in the crafting of this short film, from the writing of the narrative structure to the editing, has helped foster an epistemological disobedience and allowed the main character to feel 'fully represented'.

Figure 4. The film crew at the Festival of Venice

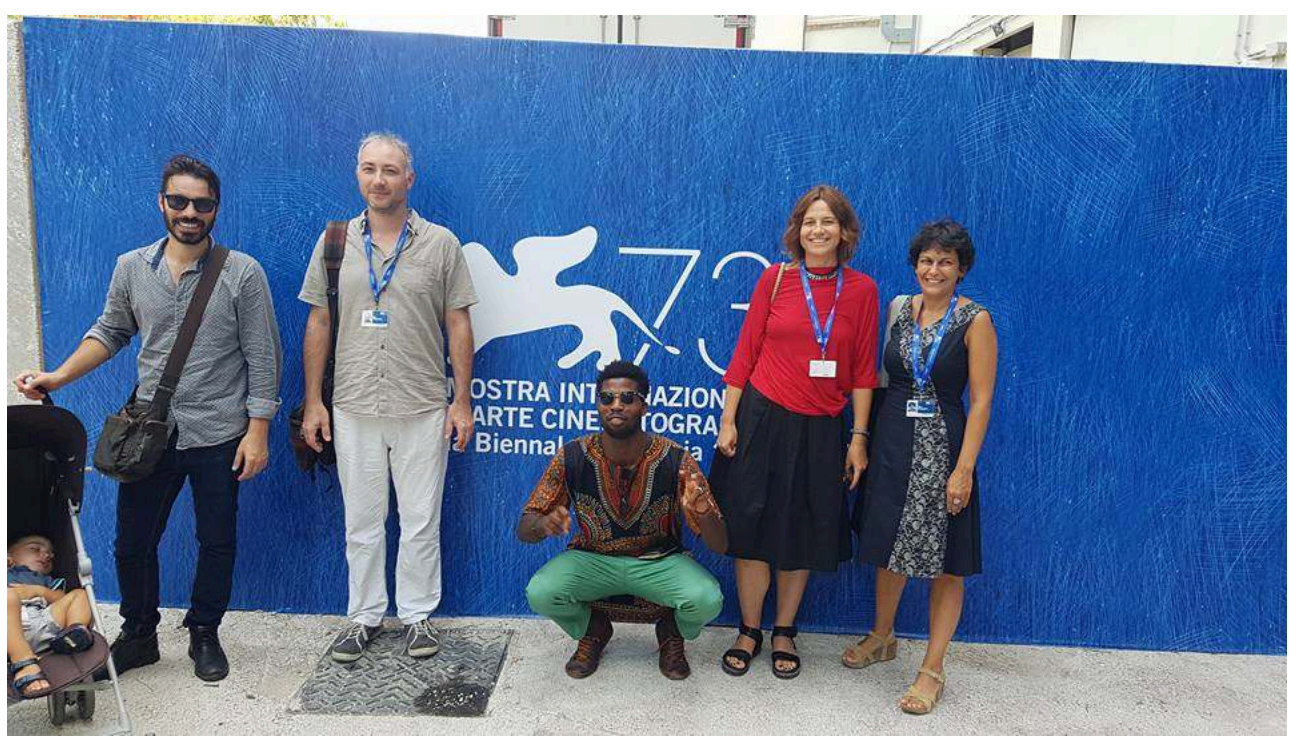

from the left: the sound engineer, the editor, the main character, the producer and the filmmaker Photo by Rossella Schillaci, 2016

\section{BIBLIOGRAPHY}

Books and articles

Bonifacio, Valentina. and Rosella Schillaci. 2017. Between Inside and Outside: Projects of Visual Research Inside Italian Prisons. Visual Anthropology 30(3): 235-248.

Chaffee, Judith and Olly Crick. 2015. The Routledge Companion to Commedia Dell'Arte. London and New York: Routledge Taylor and Francis Group.

Ciampolini, Tiziana, ed. 2007. Barriera Fragile. Rome: Ed. Idos - Collana Territorio. 
Conforti L. and A. Mela. 2006. La configurazione sociale dei diversi ambititi spaziali nella citta di Torino, Torino: IRES Piemonte.

Grimshaw, Anna. 2007. Pratica e maestria: Working with Observational Cinema. In Pratica e Maestria, DVD-book, Nota ed.

Grimshaw, Anna and Amanda Ravetz. 2009. Observational Cinema. Anthropology, Film, and the Exploration of Social Life. Bloomington and Indianapolis: Indiana University Press.

Hall, Stuart. 1990. Cultural Identity and Diaspora. In Identity:Community, Culture and Differences. Jonathan Rutherford, ed. pp. 222-237. London: Lawrence \& Wishart.

Henley, P. 2010. The Adventure of the Real: Jean Rouch and the Craft of Ethnographic Cinema. Chicago: University of Chicago Press.

Henley, Paul. 2009. In Denial: Authorship and Ethnographic Film-making (Da negacao: autoria e realizacao do filme etnografico). In Imagem-Conhecimento: antropologia, cinema e outros diálogos (pp. 101-126). Andréa Barbosa, Edgar Teodoro da Cunha and Rose Satiko Gitirana Hikiji eds. Campinas: Papirus Press.

Jenssen, T. 2009. Behind the Eye. New York: Routledge.

Pastore, Ferruccio and Irene Ponzo, (Eds.). (2016). Inter-group Relations and Migrant Integration in European Cities. Heidelberg: Springer International Publishing https://www.springer.com/gp/ book/9783319230955 (accessed August 16, 2020).

Ponzo, Irene and Ferruccio Pastore, eds. (2012). Concordia discors: Convivenza e conflitto nei quartieri di immigrazione. Rome: Carocci.

MacDougall, D. 1998. Transcultural Cinema. Princeton: Princeton University Press.

Mirzoeff, Nicolas. 2015. How to See the World. London: Penguin.

Mirzoeff, Nicolas. 2011. The Right to Look: A Counter History of Visuality. Durham, NC: Duke University Press.

Remillet, Gilles and Nadine Wanono. 2014. Collaborative and Interactive Presentation: Tracks of A Discipline Evolution. AnthroVision 2(2) https://journals.openedition.org/anthrovision/1417 (accessed August 16, 2020).

Rouch, Jean. 2003. Ciné-Ethnography. Steven Feld, ed. And trans. Minneapolis: University of Minnesota Press.

Testaverde, Anna Maria. 2007. Introduzione. In I canovacci della Commedia dell'Arte. Anna Maria Testaverde, ed. pp XVII-LXXI. Torino, Einaudi.

Worth, Sol and John Adair. 1972. Through Navajo Eyes. Bloomington: Indiana University Press.

\section{Films}

Schillaci, Rossella, dir. 2005. Pratica e Maestria (Practice and Mastery). Azul film (production). 46 $\min$.

Schillaci, Rossella, dir. 2011. Altra Europa (Other Europe). Azul film (production). 75 min.

Schillaci, Rossella, dir. 2011. Shukri, a New Life. Azul for Al Jazeera Documentary Channel (production). $22 \mathrm{~min}$.

Schillaci, Rossella, dir. 2012. Frontiera Interna. Fieri and Azul film (production). 20 min.

Schillaci, Rossella, dir. 2016. Ghetto PSA. Una Film in collaboration with Azul Film (production). 15 $\min$. 
Schillaci, Rossella, dir. 2016. Ninna Nanna Prigioniera (Imprisoned Lullaby). Indyca, De Films en Aiuguille, in collaboration with Azul film (production). $82 \mathrm{~min}$.

\section{Websites}

Concordia Discors: Integration and Conflict in European Neighbourhoods https:// concordiadiscors.fieri.it/ (accessed August 16, 2020).

Bagni Pubblici di via Agliè https://bagnipubblici.wordpress.com/ (accessed August 16, 2020).

\section{NOTES}

1. For more information about the film: https://www.facebook.com/ghettopsa/, http:// www.azulfilm.com/ghetto-psa-in-venezia/, distributed by the Royal Anthropological Institute: https://raifilm.org.uk/films/ghetto-psa/ To watch some scenes: https:// search.alexanderstreet.com/preview/work/bibliographic_entity\%7Cvideo_work\%7C3590147? ssotoken=anonymous; https://vimeo.com/243686785 (all accessed August 16, 2020)

Credits of the film:Title: Ghetto PSA. Main character: Jacob Bamba, directed by: Rossella Schillaci, produced by: Enrica Viola, DoP: Simone Rivoire, sound design: Giovanni Corona, editor: Fulvio Montano, production assistant: Mattia Plazio, color grading: Gianluca Mamino, master: DCP Stereo. 15'45" min.

2. http://concordiadiscors.fieri.it/, accessed on the 13 June 2020. Concordia Discors is funded by the European Commission through the European Integration Fund, focuses on specific neighborhoods in five European cities (Barcelona, Budapest, London, Nürnberg, Turin). The project involves five European cities, each of which is investigated by a research partner: Torino by FIERI, Nuremberg by efms of the University of Bamberg, Barcelona by the Migration Research Group of Autonomous University of Barcelona, London by COMPAS of the University of Oxford and Budapest by TARKI.

3. Frontiera Interna, Rossella Schillaci, Italy, 2012, 20 ', produced by Fieri and Azul film

4. https://bagnipubblici.wordpress.com/ accessed on 13 July 2020

5. Altra Europa (Other Europe), Rossella Schillaci, Italy, 2011, 75', produced by Azul film

6. Shukri, a New Life, Rossella Schillaci, Italy-UK, 2011, 22', produced by Azul for Al Jazeera Documentary Channel

7. Pratica e Maestria (Practice and Mastery), Rossella Schillaci, Italy, 2005, 46', produced by Azul film

8. Ninna Nanna Prigioniera (Imprisoned Lullaby), Rossella Schillaci, Italy-France, 2016, 82', produced by Indyca, De Films en Aiuguille, in collaboration with Azul film

9. Bonifacio, V., \& Schillaci, R. (2017). Between Inside and Outside: Projects of Visual Research inside Italian Prisons. Visual Anthropology, 30(3), 235-248.

\section{ABSTRACTS}

This article aims to reflect on the challenges of participatory film projects. The text analyses the method applied in the making of the short film Ghetto PSA. The main character is Jacob, a young man who arrived alone in Italy from French Guinea when he was 11 years old. He had lost his 
parents in Guinea. Today he is 27, hip hop music is his world, his personal outlet for expressing dreams, hopes and frustrations, and to no longer feel part of the 'ghetto'.

The collaborative practice with the main character of the film is analysed focusing on the different stages of production, from fieldwork, to writing and shooting. The text also analyses the influence and relation of the different figures connected to a film production, such as the producer, the characters and the crew. The article will discuss how a process of negotiation was inevitable, embracing a participative approach that brought the project into the territories of ethnofiction. This process is especially evident in the creation of an agreed scenario, which refers to the improvised and open outline of main scenes and actions (canovaccio) used in the Italian Commedia dell'Arte. This kind of 'open' scenario contributed, in my opinion, to achieve a 'transcultural' dialogue, fundamental for anthropological film-works, and also to help foster an epistemological disobedience.

Cet article a pour but de réfléchir aux défis des projets de films participatifs. Le texte analyse la méthode appliquée dans la réalisation du court métrage Ghetto PSA. Le personnage principal est Jacob, un jeune homme de Guinée française arrivé seul en Italie à l'âge de 11 ans. Il avait perdu ses parents en Guinée. Aujourd'hui, il a 27 ans, la musique hip hop est son univers, son exutoire personnel pour exprimer ses rêves, ses espoirs et ses frustrations, et pour ne plus se sentir dans le "ghetto".

Les modes de collaboration, avec le personnage principal du film, sont analysés en se concentrant sur les différentes étapes de la production, du travail sur le terrain, de l'écriture et du tournage. Le texte analyse également l'influence et la relation des différentes figures liées à la production d'un film, comme le producteur, les personnages et l'équipe. L'article explique comment un processus de négociation était inévitable, en adoptant une approche participative qui a amené le projet sur les territoires de l'ethnographie. Ce processus est particulièrement évident dans la création d'un scénario convenu, qui fait référence à l'ébauche improvisée et ouverte des scènes et des actions principales (canovaccio) utilisée dans la Commedia dell'Arte italienne. Ce type de scénario "ouvert" a contribué, à mon avis, à établir un dialogue "transculturel", fondamental pour les films anthropologiques, et à favoriser une désobéissance épistémologique.

Este artículo tiene como objetivo reflexionar sobre los desafíos de los proyectos cinematográficos participativos. El texto analiza el método usado en la realización del cortometraje Ghetto PSA. El personaje principal es Jacob, un joven que llegó a Italia solo desde la Guinea Francesa cuando tenía 11 años. Había perdido a sus padres en Guinea. Hoy tiene 27 años, la música hip hop es su mundo, su vía personal para expresar sueños, esperanzas y frustraciones, y para no sentirse más parte del 'gueto'.

Se analiza la práctica colaborativa con el protagonista de la película, centrándose en las diferentes etapas de la producción: desde el trabajo de campo, hasta la escritura y el rodaje. El texto también analiza la influencia y relación de las diferentes figuras vinculada a una producción cinematográfica, como el productor, los personajes y el equipo. El artículo discutirá cómo un proceso de negociación fue inevitable, adoptando un enfoque participativo que llevó el proyecto a los territorios de la etno-ficción. Este proceso es especialmente evidente en la creación de un escenario consensuado, que se refiere al esquema improvisado y abierto de las principales escenas y acciones (canovaccio) utilizado en la Commedia dell'Arte italiana. Este tipo de escenario 'abierto' contribuyó, en mi opinión, a lograr un diálogo 'transcultural', fundamental para las obras cinematográficas antropológicas, y también a ayudar a fomentar una desobediencia epistemológica. 
INDEX

Palabras claves: cine documental, cine etnográfico, métodos colaborativos, autoría, práctica transcultural, etnoficción

Keywords: documentary film, ethnographic film, collaborative methods, authorship, transcultural practice, ethnofiction

Mots-clés: film documentaire, film ethnographique, méthodes collaboratives, auteurs, pratique transculturelle, ethnofiction

\section{AUTHOR}

\section{ROSSELLA SCHILLACI}

Doctoral candidate in a research program at Nova University of Lisbon, in collaboration with the University of Turin and the University of Texas in Austin, funded by FCT; filmmaker at Azul, www.azulfilm.com

rossellasch@yahoo.com 